\title{
Relationship of Parents and the Child - Factor Affecting Education of Children with Disability
}

\author{
Adéla Hanáková, Buqiong, Eva Urbanovská, Iva Dokoupilová, Jana Soldanová, Li Xinrui, \\ Miloň Potměšil, Nikola Štěpničková, Simona Kmentová, Vladimíra Zedková
}

\begin{abstract}
The present article deals with the relationship between parents and their child as one of the factors affecting education of handicapped children. The article further introduces the project entitled "Description of Selected Factors of Education and Upbringing of Handicapped Individuals I III“. The present project aims at characterisation of specific factors of education and upbringing of handicapped children. The project consists of three stages - stage one focused on school children (implemented in 2015), stage two dealing with parents (in 2016) and stage three studying teachers (to be implemented in 2017) of handicapped children. The purpose of the present contribution is to search and summarise existing research and completed projects on the same or similar theme, their characteristics, analysis and results.
\end{abstract}

Keywords - relationship, parent, child, handicap, education, search

\section{INTRODUCTION}

$\mathrm{F}$ amily is one of the major factors affecting the life and development of every child. Especially the family of a handicapped child must be considered the major factor affecting the child's development. Michalík (2013) notes that all attempts to replace the family with an institution in this respect have failed so far. Hartl and Hartlová (2013) define the family as a community based on marriage and blood relationship. Another approach to the definition of family is introduced by Linhart and Petrusek (1996), who define the family as an original and most important social group, the basis of social structure and the basic economic unit. They also define its main functions including human reproduction and child upbringing and socialisation. Family roles are also defined by Reichel (2008), who speaks of biological reproductive, economic, defensive, therapeutic - care, cultural - reproductive, educational and upbringing roles of the family.

Phd Student, Institute of Special Education Palacký University Olomouc Czech Republik
The family successfully performing its roles in relation to the individual family members is called eufunctional family. Families successfully performing their roles but being in a certain conflict with general standards and values may be called dysfunctional, and families not performing their roles are classified as non-functional. (Reichel, 2008) Šed'ová (2004) say that the family size also affects the child's education, introducing their hypothesis on "source dilution". Their hypothesis is based on the assumption that parents dispose with a certain quantity of sources they are able to put into education of their children. If there are more children in the family these sources must be distributed among them. According to this hypothesis children from bigger families with more children receive fewer parental sources.

Another factor affecting the child's education is the sequence in which the children are born. This issue was studied already in the past century by Alfred Adler. (1999) He supported the thesis that the only and the first born children are under increased parental attention and demand.

\section{SURVEY OF ARTICLES AND RESEARCH}

Research based on Rohner questionnaire for parents (PARQ -R) was implemented under the specific conditions of the Czech Republic by Vágnerová, Strnadová, Krejčířová (2009). The purpose of the research was to evaluate mother's approach to her child. Rohner questionnaire PARQ $-\mathrm{R}$ was used for comparison of approaches of mothers of handicapped and intact children. The target group was represented by mothers of children with cerebral palsy and Down syndrome. The PARQ - R questionnaire assessed 4 areas of approach to the child - "affection and love of the mother given to her child, hostility and trends towards aggressive behaviour towards the child, lack of interest in the child, indolence and neglect, emotional refusal of the child“. (Vágnerová, Strnadová, Krejčíŕová, 2009, p. 145)

The authors did not find any differences in the mothers' approach to their children. Further studied factors included age and education of the mothers. These factors did not prove to be decisive either. The type of handicap did not play any role in the mother's approach to her child. The authors therefore concluded that the only factor affecting the mother's approach 
to her child is the personality of the mother.

A similar research in the environment of the United States of America was performed by Suzanne Button, Robert C. Pianta and Robert S. Marvin (2001). They interviewed 112 mothers of children at the age of 14 to 52 months. Of this number 59 , i.e. $51 \%$, were mothers of children with diagnosed cerebral palsy and 19 (17\% of the sample) were mothers of children with epilepsy. The research was focused on the relationship between the mother's approach to her child and the mother's age, education, stress to which the mother is exposed, level of the child's psychomotoric development and type of the child's handicap. Severe handicap proved to be the origin of disharmony in the mother-child relationship and difficulty of assessment of this relationship by the mother. Also longer diagnostic process proved to be an obstacle to this assessment. On the other hand the mother's assessment of her relationship to her child was not affected by the child's gender, age, mother's age and education and the level of stress to which the mother was exposed. The level of the mother's education however proved to negatively affect her worries about the future of her child.

Another research on the relationship between parent and child was performed by Jeniffer Messina Sayre, Robert S. Pianta, Robert S. Marvin and Elisabeth W. Saft (2001). This research focused on the mother's view of her relationship to the child and their relation to the mother's characteristic and sensitivity to the child's feeding. The research involved 58 mothers of children with cerebral palsy at the age of 16 to 52 months. Data were collected through structured interviews of the Parent Development Interview (DPI) type. The purpose of the research was to describe the relation between the mother's view of her relationship to her child and demographic characteristics, severity of the diagnosis and developmental level of the child. Mothers more afraid that they would not be able to fulfil their parental role showed less sensitivity, pleasure and acceptance during the child's feeding. Mothers with more emotional problems also showed higher levels of hostility. On the other hand mothers more afraid of the wellbeing of the child showed more sensitivity and pleasure. Also worries about the child's future significantly affected behaviour of the mothers feeding their children.

Cohesion of families with handicapped children was dealt with by Abbas Ali Hosseinkhazdeh, Mehdi Esapoor, Taiebeh Yeganeh and Reza Mohammadi (2013) in the years 2007 2008. The purpose of their research was to describe cohesion of families with children with mental handicap. The research sample consisted of 138 families of pupils with mental handicap. Family cohesion was measured on the Bloom and Naar's scale of family cohesion. The authors mainly emphasized that cohesion of families with a mentally handicapped child is a significant source of support. The study was based on the finding that care of a person with mental handicap often causes distress in the other family members. The study analysed the effect of the child's gender, level of education and parent level of education on family cohesion.
The research included 138 pupils with mental handicap and no other associated disability. The study population included 65 girls (of which 30 elementary school pupils and 35 higher education institute students) and 73 boys (of which 31 elementary school pupils and 42 higher education institute students). The test showed no relation between the child's gender and level of education and family cohesion. However, the test revealed a relation between understanding of family cohesion and level of parent education. The authors themselves note, though, that generalisation of the research results should be done with care. This research is related to the research on the relationship of siblings to their mentally handicapped brother or sister. The team of authors Hosseinkhanzadeh Abbas Ali, Esapoor Mehdi and Yeganeh, Taiebeh (2013) focused on siblings of handicapped children. The research sample consisted of 138 families with children with mental handicap. Data collection was based on the behavioural indexes of siblings (SIB) scale. The research showed that the quality of relationships between siblings decreases with age and that there is a substantial difference between understanding of the quality of the relationship between siblings on the part of the mother and the father.

The issue is viewed from the angle of relationships within families with handicapped children by Ulrike Bremen - Hübler (1990). The purpose of her research was to describe the effect of psychic and physical stress of mothers of children with mental handicap in school age on development of family relations and social integration of the handicapped child. The research sample consisted of 55 mothers and 61 children with mental handicap. Data collection was based on questionnaire and structured interview. The research showed that mothers of children with mental handicap spend more time taking care of their children in comparison to families with intact children but they are mostly satisfied in their carer role.

Similar research was performed in Germany by Klaus Sarimski. in 2010, who analysed the level of subjective stress of mothers with children with severe mental disorder. According to the author mothers with high Parenting Stress Index represent a high risk group. The psychic stress that may develop may negatively affect mother-child interaction. Up to two thirds of the addressed mothers admitted a high level of stress and psychic tension. The level of subjective tension however did not depend on the type and level of the child's handicap but rather on the child's behaviour and its problems in everyday life, on individual and social sources available to the family and care provided to the family. The research showed that one of the things families with handicapped children need is family advisory service.

Stress and coping is also subject of the research performed by Barbara Gabriel, Nadine Zeender and Guy Bodenmann (2008) in parents of children with Down syndrome. The research focused on the relation between stress, individual, dyadic and social sources of the family. The research showed that although material sources are important for families with children with Down syndrome to cope with everyday stress 
individual and social sources cannot be underestimated either. The data were collected by means of a questionnaire specially compiled for parents of children with Down syndrome. The research sample included 75 parents with a child with Down syndrome (of which 34 girls and 41 boys) at the age of $2-11$ years. The studied variables included demographic data such as age, education level and occupation of the parents.

Cooperation between the school and the family with a handicapped child is addressed by Klauß Theo, Wolfgang Lamers and Frauke Janz (2007). Their questionnaire-based inquiry focused on the standards of cooperation between the school and the family with a handicapped child and how the parent see the offer of education for their child. The questionnaire inquiry was performed in 109 elementary schools for pupils with special needs in the federal republic of Baden-Württemberg. Similar research in US environment was performed in 1988 by Christine Salisbury and Ian M Evans (1988). Their research focus was comparison of the options of involvement of parents of intact and handicapped children in their education. The research enrolled 17 parents and showed that parents of handicapped children are provided more options of engagement in their child's education. The research did not show, though, that parent involvement in education of their children would be affected by the type or severity of the child's handicap.

Selected aspects of relationship between parents and children with handicap were studied by the German author Daniela Helfer (2010). Her study focused on the effect of the stress of upbringing of a handicapped child on the family and family relations, development of the handicapped child and ideas of the parents of the handicapped child about their child's future. To that end the author interviewed 20 mothers and 8 fathers of handicapped children. The research focused on how the birth of the handicapped child affected family relations, which stages of the child's development (the stage immediately after birth, the birth, enrolment in nursery, transition from the nursery to the elementary school, education completion and transition to an occupation) were seen by the parents as most demanding. Further inquiries focused on which factors of the child's development were retrospectively seen by the parents as exceptionally demanding (for example social relationships, lack of information, experience in health care of a handicapped child, increased attention of the surrounding etc.) and on the effect of the level of education of the parents on their ideas about the future of their handicapped child.

Another view of the relationship between the parent and the child with handicap is brought in by a group of authors including Stephanie W. Cawton, Carrie Lou Garberoglio, Jacqueline M. Caemmerer, Mark Bond and Erica Wendel (2015). Their research deals with the period after completion of education and chances of individuals with hearing impairment on the job market and focuses on the effects of parent and their expectations on job search and work results of individuals with hearing impairment. The study was based on the fact that unemployment rates in the population with hearing impairment are higher in comparison to the intact population. Data collection used the data set of the National Longitudinal Transition Survey 2 (NLTS-2).

Research on the effect of the family on child's education at the age between 3 and 8 years was performed in 2013 by Frances L. Van Voorhis, Michelle Maier, Joyce L. Epstein and Chrishana M. Lloyd. Their research concentrated on literary, mathematical and social - emotional qualities of the children. The research took 10 years. For data collection purposes 95 families were monitored. The following 4 areas were studied: learning at home (engagement of parents in improvement of skills of their children outside school), parents' involvement in school activities (family - school interactions), school activities focusing on family involvement (school activities and interventions aimed at parental involvement in their child's education), support of parental activities (support for the parent-child relationships, parental intervention in home work of their children). The study confirmed that involvement of parents in the child's learning in and outside school supports development of the child's knowledge and skills. Families in socially unfavourable situation may support development of knowledge and skills of their child in the same way if they are guided by the school.

The difference between mother-child and father-child relationships was studied by Tamar Heller, Kelly Hsieh and Louis Rowitz in 1997. The study compared the dimension of upbringing and care of a mentally handicapped child in mothers and fathers. The study focused on both children living in the family and children under institutional care. Mothers provided more care and support to their children than fathers. The research sample consisted of 113 families with a mentally handicapped child, $50 \%$ of which brought up in and $50 \%$ outside their families. 58\% of the children were boys and $42 \%$ were girls. The studied parameters include the child's age, gender and whether the child was brought up in or outside its family, the child's behaviour and socio-economic status of the family. Child's behaviour was measured by ICAP (Inventory for Client and Agency Planning maladaptive scale). The study showed that there is a relationship between the child's age and gender and the time spent by care of it by the mother and the father. at the same time there was a relation between the child's upbringing in or outside the family and the time spent by care of it by the mother and the father.

The last research in this field is represented by Hea-Won Kim, Greenberg, J. S., Seltzer, M. M., Krauss, M. W (2003). The research focused on the role of cooping and psychic wellbeing of mothers of children with mental handicap or disease. The research was based on the finding that mothers of children with mental handicap or disease must provide lifelong care to their child which brings about exposure to psychic stress. The study describes transformations of the coping strategies with the child's age. The research involved 246 mothers of children with mental handicap and 76 mothers of children with mental disease. In both groups emotion-focused coping strategies decreased psychic well-being. Support for coping strategies of 
mothers of children with mental handicap focused on the issue reduced their stress and improved their relationship to their child. Support for coping strategies of mothers of children with mental disease did not lead to stress reduction bud also improved the mother's relationship to her child.

\section{OUR RESEARCH INTRODUCTION}

The above described search shows that little attention is paid in professional literature to the theme of the parent-child relationship and education of children with handicap. In the Czech Republic there is only a couple of qualification theses dealing with the theme. That is why a research project currently in progress in the Czech Republic will be introduced.

The introduced research project is the second stage of research focused on "Description of selected factors of education and upbringing of individuals with handicap I. III.“ The project focuses stepwise on handicapped elementary school pupils (2015), their parents (2016) and their teachers (2017). The target group of the second project stage is children at the age of $9-15$ years. They include pupils with physical, hearing and vision handicaps with intact pupils as the control group. The pupils were presented with the standardised PARQ questionnaire, modified according to the particular type of the child's handicap. For children with hearing impairment the questionnaire was interpreted in the Czech sign language and for children with impaired vision large font print was used, while for blind children the text was transcribed in Braille. The option of transcription to Braille was not used by any of the inquired children. Data collection started in May 2016 and is approaching its end now. The respondents included pupils of elementary schools for children with special needs and the control sample was recruited from standard elementary and grammar schools. The studied parameters included the child's age and type of handicap and, last but not least, the questionnaires were paired with the same questionnaires filled out by their mothers and fathers.

This article was supported by grant IGA_PdF_2015_013.

\section{SOURCES}

[1] Michalík, J. (2013). Rodina pečujici o člena se zdravotním postižením kvalita života. [Family taking care of a handicapped member - quality of life]. [electronic source]. Olomouc: Palacký University in Olomouc

[2] Hartl, P., \& Hartlová, H. (2000). Psychologický slovník [Psychological dictionary]. Prague: Portal.

Linhart J., Petrusek, M. (1996) Velký sociologický slovník [Big sociological dictionary]. Prague: Karolinum.

[3] Reichel, J. (2008) Kapitoly systematické sociologie [Chapters in systematic sociology]. Prague: Grada,

[4] Šed'ová, K. (2004) Vzdělávací výsledky dětí: vliv rodiny [Study results of children - family influence] in Rabušicová, M., Šed’ová, K., Trnková, K. et al, Škola a (versus) rodina [School and (versus) family]. Brno: Masaryk University.

[5] Vágnerová, M., Krejčová, L., \& Strnadová, I. (2009). Náročné mateřství: být matkou postiženého dítěte [Demanding maternity: how to be mother of a handicapped child]. Prague: Charles University in Prague, Karolinum Publishers.

[6] Button, S., Pianta, R. C., \& Marvin, R. S. (2001). Mothers' Representations of Relationships with their Children: Relations with Parenting Behavior, Mother Characteristics, and Child Disability Status. Social Development, 10(4), 455-472. https://doi.org/10.1111/1467-9507.00175

[7] Messina Sayre, J., Pianta, R. C., Marvin, R. S., \& Saft, E. W. (2001). Mothers' representations of relationships with their children: Relations with mother characteristics and feeding sensitivity. Journal Of Pediatric Psychology, 26(6), 375-384. doi:10.1093/jpepsy/26.6.375 https://doi.org/10.1093/jpepsy/26.6.375

[8] Bremer-Hübler, U. (1990). Streß und Streßverarbeitung im täglichen Zusammenleben mit geistig behinderten Kindern : Eine empirische Studie zur Situation der Mütter. Frankfurt a. M.: Lang.

[9] Hosseinkhanzadeh, A. A., Esapoor, M., Yeganeh, T., \& Mohammadi, R. (2013). A Study of the Family Cohesion in Families with Mentally Disable Children. Procedia - Social And Behavioral Sciences, 84(The 3rd World Conference on Psychology, Counseling and Guidance, WCPCG-2012), 749-753. doi:10.1016/j.sbspro.2013.06.639 https://doi.org/10.1016/j.sbspro.2013.06.639

[10] Sarimski, K. (2010). Mütter mit jungen (schwer) geistig behinderten Kindern: Belastungen, Bewältigungskräfte und Bedürfnisse. Frühförderung Interdisziplinär, 29(2), 62-72. https://doi.org/10.2378/fi2010.art07d

[11] Gabriel, B., Zeender, N., \& Bodenmann, G. (2008). Stress und Coping bei Eltern von einem Kind mit einem Down-Syndrom : Die Überprüfung eines theoretischen Modells. Zeitschrift Für Familienforschung, 20(1), 80-95.

[12] Klauß, T., Lamers, W. Janz, F. (2007). Die Kooperation zwischen Schule und Eltern von Kindern mit schwerer und mehrfacher Behinderung. Geistige Behinderung, 46(4), 295-308.

[13] Salisbury, C., \& Evans, I. M. (1988). Comparison of Parental Involvement in Regular and Special Education. Journal Of The Association For Persons With Severe Handicaps (JASH), 13(4), 26872. https://doi.org/10.1177/154079698801300405

[14] Helfer, D., \& Fries, A. (2010). Belastungen in Familien mit behinderten Kindern unter ausgewählten Aspekten. Behindertenpädagogik, 49(3), 297-312.

[15] Cawthon, S. W., Garberoglio, C. L., Caemmerer, J. M., Bond, M., \& Wendel, E. (2015). Effect of parent involvement and parent expectations on postsecondary outcomes for individuals who are d/Deaf or hard of hearing. Exceptionality, 23(2), 73-99. doi:10.1080/09362835.2013.865537 https://doi.org/10.1080/09362835.2013.865537

[16] Van Voorhis, F. L., Maier, M. F., Epstein, J. L., Lloyd, C. M., \& MDRC. (2013). The Impact of Family Involvement on the Education of Children Ages 3 to 8: A Focus on Literacy and Math Achievement Outcomes and Social-Emotional Skills. Mdrc

[17] Heller, T., Hsieh, K., \& Rowitz, L. (1997). Maternal and Paternal Caregiving of Persons with Mental Retardation across the Lifespan. Family Relations, (4). 407. https://doi.org/10.2307/585100

[18] Hosseinkhanzadeh, A. A., Esapoor, M., \& Yeganeh, T. (2013). A Study of the Siblings Relationships in Families with Mentally Disable Children. Procedia - Social And Behavioral Sciences, 84(The 3rd World Conference on Psychology, Counseling and Guidance, WCPCG2012), 864-868. doi:10.1016/j.sbspro.2013.06.663. https://doi.org/10.1016/j.sbspro.2013.06.663

[19] Adler A. (1999). Porozuměni životu: úvod do individuální psychologie [Understanding life: Introduction to individual psychology]. Prague: Aurora 